\title{
Streptomyces scopiformis sp. nov., a novel streptomycete with fastigiate spore chains
}

\footnotetext{
${ }^{1}$ State Key Laboratory of Microbial Resources, Institute of Microbiology, Chinese Academy of Sciences, Beijing 100080, People's Republic of China

2 BCCM/LMG Bacteria Collection, Department of Biochemistry, Physiology and Microbiology, Universiteit Gent, K. L. Ledeganckstraat 35, B-9000 Gent, Belgium
}

\author{
Wei Li, ${ }^{1}$ Benjamin Lanoot, ${ }^{2}$ Yamei Zhang, ${ }^{1}$ Marc Vancanneyt, ${ }^{2}$ \\ Jean Swings ${ }^{2}$ and Zhiheng Liu ${ }^{1}$ \\ Author for correspondence: Zhiheng Liu. Tel: +86 10 62553628. Fax: +86 1062560912. \\ e-mail: zhliu@sun.im.ac.cn
}

\begin{abstract}
A distinct actinomycete strain was isolated from rhizosphere soil of Tsuga chinensis. The isolate, designated A25', was assigned to the genus Streptomyces on the basis of morphological and chemotaxonomic criteria and was examined by using a polyphasic approach. An almost complete 165 rDNA sequence of the isolate was determined and compared with sequences of representative streptomycetes. The 165 rDNA data not only supported classification of the strain in the genus Streptomyces, but also showed that it formed a separate phyletic line. DNA-DNA hybridization between strain A25 ${ }^{\top}$ and closely related reference strains confirmed that strain $A 25^{\top}$ is a novel taxon of Streptomyces. It is proposed, therefore, the strain $\mathrm{A25}^{\mathrm{T}}$ (= AS 4.1331' $=$ LMG 20251') is classified in the genus Streptomyces as Streptomyces scopiformis sp. nov.
\end{abstract}

Keywords: Streptomyces scopiformis sp. nov., polyphasic taxonomy, 16S rDNA sequence, DNA-DNA hybridization

\section{INTRODUCTION}

The genus Streptomyces was proposed by Waksman \& Henrici (1943) for aerobic, spore-forming actinomycetes and is classified in the family Streptomycetaceae on the basis of morphological and cell-wall chemotaxonomic characters. The taxon currently accommodates aerobic, Gram-positive bacteria that have high DNA $\mathrm{G}+\mathrm{C} \%$ content (69-78 $\mathrm{mol} \%$ ), present LL-diaminopimelic acid and the absence of characteristic sugars in the cell wall (cell-wall type I, according to Lechevalier \& Lechevalier, 1970) and produce extensively branched substrate mycelium and aerial hyphae (Williams et al., 1983, 1989; Embley \& Stackebrandt, 1994). With more than 500 validly described species and subspecies, the taxon currently contains the largest number of species in the domain Bacteria (Hain et al., 1997).

Molecular-systematic methods, notably 16S rDNA phylogenetic analysis, are having an increasing impact on Streptomyces systematics (Kim et al., 1998). Of the

Published online ahead of print on 14 June 2002 as DOI 10.1099/ ijs.0.02130-0.

The GenBank accession numbers for the 16S rDNA sequences of Streptomyces scopiformis $\mathrm{A} 25^{\top}$ and Streptomyces lateritius AS $4.1427^{\top}$ are AF184081 and AF454764. large number of species, complete $16 \mathrm{~S}$ rDNA sequences have not been determined for many type strains. Incomplete sequence data may result in misclassification. It has been reported that the $\gamma$ variable region of $16 \mathrm{~S}$ rDNA could be used to resolve inter- and intraspecies relationships within the streptomycetes (Kataoka et al., 1997; Anderson \& Wellington, 2001). Hence, partial sequences covering the $\gamma$ region (positions 158-276) of 485 streptomycetes have been sequenced and deposited in GenBank by K. Ueda, T. Kudo, T. Seki, T. Yoshida and M. Kataoka. Phylogenetic analysis including these sequences can provide useful information for classification and reduce the risk of incorrect identification.

Isolate $\mathrm{A} 25^{\mathrm{T}}$ was reported previously as a novel taxon, 'Streptomyces scopiformis', that produced distinct broom-like spore chains (Liu \& Zhang, 1996), but the name was not validated. In the present study, strain A $25^{\mathrm{T}}$ was subjected to a polyphasic taxonomic analysis, an almost complete 16S rRNA gene (rDNA) sequence was obtained and its phylogenetic relationships were examined using different tree-making methods. DNA-DNA hybridization of isolate A25 and its closest neighbours was studied in order to reveal whether the isolate represents a novel taxon within the genus Streptomyces. 


\section{METHODS}

Organisms and cultural conditions. Strain $\mathrm{A} 25^{\mathrm{T}}$ was isolated on a glycerol/asparagine agar plate (glucose, $10 \mathrm{~g}$; Lasparagine, $0.5 \mathrm{~g}$; agar, $20 \mathrm{~g}$; distilled water $1000 \mathrm{ml} ; \mathrm{pH}$ $7 \cdot 2-7 \cdot 4)$ seeded with a soil sample suspension and incubated for 14 days at $28{ }^{\circ} \mathrm{C}$. The soil sample was collected from the rhizosphere of Chinese hemlock (Tsuga chinensis) in Lushan Mountain, Jiangxi province, China.

The novel isolate and reference strains were maintained on slopes of Bennett's agar (Williams et al., 1983) at $4{ }^{\circ} \mathrm{C}$ and as glycerol suspensions $(20 \%, \mathrm{v} / \mathrm{v})$ at $-20^{\circ} \mathrm{C}$. Biomass for chemotaxonomic and molecular studies was prepared by growing organisms in $250 \mathrm{ml}$ flasks containing $80 \mathrm{ml}$ Bennett's medium (prepared in $0.01 \mathrm{M}$ phosphate buffer, $\mathrm{pH}$ $7 \cdot 0$ ) with shaking for 4 days at $28^{\circ} \mathrm{C}$. The flasks were inoculated by transferring a 4-day-old culture from Bennett's agar slopes (prepared in 0.01 M phosphate buffer, $\mathrm{pH} 7 \cdot 0$ ) with $2 \mathrm{ml} \mathrm{0 \cdot 1} \mathrm{M}$ phosphate buffer $(\mathrm{pH} 7 \cdot 0)$. Cells for chemical studies were washed in distilled water and freeze-dried; those for molecular systematic investigations were washed twice in distilled water and Tris/EDTA $(0.03 \mathrm{M}$ Tris/ $\mathrm{HCl}, 0.1 \mathrm{M}$ EDTA, pH 8.0) and stored at $-20^{\circ} \mathrm{C}$ until required.

Cultural and morphological properties. The morphology of aerial hyphae, substrate mycelium and spore chains was examined by light and scanning electron microscopy of a 14 day culture grown on Bennett's agar and inorganic salts/ starch agar (ISP medium 4). The cover-slip technique (Zhou et al., 1998; Kawato \& Shinobu, 1959) was used to observe hyphae and spore chains by light microscopy. Spore morphology was studied by examining gold-coated dehydrated specimens with a model HITACHI-570 electron microscope. The cultural characteristics were observed on a number of media for 14 days at $28^{\circ} \mathrm{C}$.

Biochemical and physiological properties. The test strain were examined for a broad range of biochemical and physiological characteristics as described by Kämpfer et al. (1991), Williams et al. (1983) and Al-Tai et al. (1999).

Chemotaxonomy. The diagnostic isomers of diaminopimelic acid (DAP) and whole-organism sugars of the test strain were analysed following the procedures developed by Hasegawa et al. (1983) and Lechevalier et al. (1977). Menaquinones and phospholipids were extracted from freezedried biomass and purified according to Collins (1985) and Lechevalier \& Lechevalier (1970) and analysed by HPLC (Warwick et al., 1994). The resultant fatty acids were prepared and analysed using the procedure described by Minnikin et al. (1980).

DNA G + C content. The $\mathrm{G}+\mathrm{C}$ content of DNA of the test strain was determined using the thermal denaturation method of Marmur \& Doty (1962) with Escherichia coli AS1.365 as a control.

16S rDNA sequencing. Genomic DNA of test strains was isolated using the procedure of Chun \& Goodfellow (1995). PCR amplification of $16 \mathrm{~S}$ rDNA was carried out as described previously (Kim et al., 1996). The PCR products were sequenced using the method of Lu et al. (2001) on an Applied Biosystems DNA Sequencer (model 373A) and the software provided by the manufacturer.

Phylogenetic analysis. The almost complete 16S rDNA sequence of strain $\mathrm{A} 25^{\mathrm{T}}$ was aligned manually with available streptomycete nucleotide sequences retrieved from EMBL/ GenBank and the RDP (Maidak et al., 1997) using CLUSTAL $\mathrm{X}$ version 1.8 (Thompson et al., 1997). Phylogenetic trees were inferred by using three tree-making algorithms, the neighbour-joining (Saitou \& Nei, 1987), Fitch-Margoliash (Fitch \& Margoliash, 1967) and maximum-likelihood (Felsenstein, 1981) algorithms from the PHYLIP package (Felsenstein, 1993). Evolutionary distance matrices were generated as described by Kimura (1980). Tree topologies were evaluated by carrying out bootstrap analysis based on 1000 resamplings of the neighbour-joining dataset using the programs SEQBOOT and CONSENSE provided in the PHYLIP package (Felsenstein, 1993).

The partial sequence covering the $\gamma$ region $(120 \mathrm{bp})$ from the $16 \mathrm{~S}$ rDNA sequence of strain $\mathrm{A} 25^{\mathrm{T}}$ was compared with all sequences available in GenBank. The partial sequence was also aligned with partial $\gamma$-region sequences of 485 streptomycetes and used for construction of a neighbour-joining tree.

DNA-DNA relatedness studies. Levels of DNA-DNA relatedness between strain $\mathrm{A} 25^{\mathrm{T}}$ and the type strains of Streptomyces ambofaciens, Streptomyces coerulescens, Streptomyces caelestis, Streptomyces nogalater, Streptomyces intermedius, Streptomyces albidoflavus and Streptomyces lateritius were determined according to the thermal renaturation method (De Ley et al., 1970; Huß et al., 1983; Yassin et al., 1993) using a UV-1206 spectrophotometer (Shimadzu) equipped with a TB-85 thermobath.

\section{RESULTS AND DISCUSSION}

The almost complete 16S rDNA sequence of strain A $25^{\mathrm{T}}$ (1402 nt) was determined. The sequence data clearly showed that strain A25 $5^{\mathrm{T}}$ is a member of the genus Streptomyces. The chemotaxonomic data confirmed the generic assignment. The presence of LLDAP and the absence of characteristic sugars in wholecell hydrolysates showed that strain $\mathrm{A} 25^{\mathrm{T}}$ had wall type I (Lechevalier \& Lechevalier, 1970). The strain also contained tetra- and hexahydrogenated menaquinones with nine isoprene units as the predominant isoprenologue. The phospholipid pattern is type PII (containing phosphatidylethanolamine and diphosphatidylglycerol). Strain A25 showed a fatty acid profile typical of Streptomyces (type IIc according to Kroppenstedt, 1985), with iso-C15:0 (21.5\%), anteiso-C15:0 (13.2\%), iso-C16:0 (18.9\%) and $\mathrm{C} 16: 0$ $(13.5 \%)$ predominant. The DNA $\mathrm{G}+\mathrm{C}$ content of strain $\mathrm{A} 25^{\mathrm{T}}$ is $71 \mathrm{~mol} \%$.

The phenotypic properties are also consistent with the classification of strain $\mathrm{A} 25^{\mathrm{T}}$ in the genus Streptomyces. Strain $\mathrm{A} 25^{\mathrm{T}}$ grew poorly on inorganic media, while it grew well on organic media, producing abundant branching mycelium. The substrate mycelium is light blue/Paris blue to brown blue, consists of septate and swollen elements and does not fragment. The aerial mycelium tends to be blue grey/light blue grey and differentiates into long, rectiflexibles spore chains with spiny surfaces. The spore chains are derived from the point of a sporosphore and are often arranged in a fastigiate structure (Fig. 1). No verticillate structure is detected. The fastigiate structure of strain $\mathrm{A} 25^{\mathrm{T}}$ is distinct from that of other streptomycetes. Verticillate streptomycetes produce similar structures, but verticillate spore chains form regularly with smooth spore 


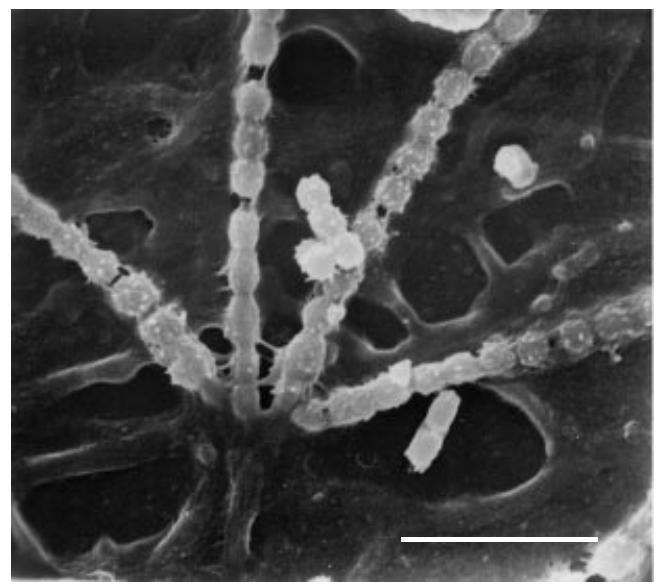

Fig. 1. Scanning electron micrograph of strain $A 25^{\top}$ grown on Bennett's agar for 14 days at $28^{\circ} \mathrm{C}$. Bar, $6 \mu \mathrm{m}$.

surfaces, whereas the fastigiate spore chains were produced randomly and the spore surface was spiny. The diagnostic characteristics of strain $\mathrm{A} 25^{\mathrm{T}}$ and related strains are listed in Table 1.

It is clear from the phylogenetic tree that strain $\mathrm{A} 25^{\mathrm{T}}$ forms a single branch separate from other representatives of the genus Streptomyces (Fig. 2), notably from its nearest neighbours S. ambofaciens $(97.75 \%)$, the blue-mycelium strain Streptomyces coelicolor A3(2) $(97.56 \%)$ and $S$. coerulescens $(97.55 \%)$. The branch was supported by a bootstrap value of $74 \%$ and by the results of the Fitch-Margoliash and maximumlikelihood methods. It has been shown that the discriminative power of $16 \mathrm{~S}$ rRNA sequencing is limited when closely related organisms are being inspected (Yassin et al., 1997), especially for members of the genus Streptomyces. Carefully selected phenotypic traits and DNA-DNA pairing data are therefore needed to differentiate Streptomyces species that share very similar 16S rDNA sequences (Kim et al., 1998; Labeda, 1988). In order to clarify the finer relationships, DNA-DNA association studies were carried out between strain $\mathrm{A} 25^{\mathrm{T}}$ and closely related strains selected on the basis of their 16S rDNA sequence similarity and phylogenetic positions. The low DNADNA relatedness between strain $\mathrm{A} 25^{\mathrm{T}}$ and $S$. ambofaciens AS $4 \cdot 1528^{\mathrm{T}}(13 \cdot 1 \%), S$. coerulescens JCM $4358^{\mathrm{T}}(34 \cdot 3 \%)$, S. caelestis JCM $4218^{\mathrm{T}}(23.4 \%)$, S. nogalater JCM $4799^{\mathrm{T}}(31 \cdot 4 \%)$, S. intermedius JCM. $4483^{\mathrm{T}}(26.3 \%)$ and $S$. albidoflavus JCM $4446^{\mathrm{T}}$ $(19 \cdot 6 \%)$ confirmed that strain $\mathrm{A} 25^{\mathrm{T}}$ can be considered as a novel taxon. This is also supported by phenotypic data, as at least five differences in phenotypic properties were observed between strain $\mathrm{A} 25^{\mathrm{T}}$ and its closest neighbours $S$. ambofaciens, $S$. coerulescens and $S$. coelicolor (Table 1).

Analysis of partial $\gamma$ region sequences showed that strain $\mathrm{A} 25^{\mathrm{T}}$ was grouped into a branch with $S$. lateritius JCM 4389' and 'Streptomyces flavochromogenes' JCM 4752 (data not shown), but analysis of almost complete $16 \mathrm{~S}$ rDNA sequences showed that S. lateritius JCM $4389^{\mathrm{T}}$ fell into a branch with Streptomyces venezulae that was distinct from strain A $25^{\mathrm{T}}$. The low DNA-DNA relatedness $(17 \cdot 4 \%)$ between S. lateritius JCM $4389^{\mathrm{T}}$ and strain $\mathrm{A} 25^{\mathrm{T}}$ also confirmed that they are different species.

In conclusion, the genotypic, chemotaxonomic and phenotypic data show that strain $\mathrm{A} 25^{\mathrm{T}}$ forms a novel

Table 1. Diagnostic characteristics of strain $A 25^{\top}$ and related strains

Characters are scored as: + , Positive; - , negative. D, doubtful. All four strains are positive for utilization of D-glucose, D-xylose, $\mathrm{L}$-arabinose, D-fructose and D-galactose.

\begin{tabular}{|c|c|c|c|c|}
\hline Characteristic & Strain $A 25^{T}$ & $\begin{array}{c}\text { S. ambofaciens } \\
\text { JCM 4342 }\end{array}$ & $\begin{array}{l}\text { S. coerulescens } \\
\text { JCM 4389 }\end{array}$ & $\begin{array}{c}\text { S. coelicolor } \\
\text { DSM 40233 }\end{array}$ \\
\hline Spore chain morphology* & $\mathrm{RF}$ & RF & SP & $\mathrm{RF}$ \\
\hline Spore surface & Spiny & Smooth & Spiny & Smooth \\
\hline Melanoid pigment & - & - & + & - \\
\hline Diffusible pigment & - & - & + & + \\
\hline $\mathrm{pH}$ indicator & + & - & - & + \\
\hline \multicolumn{5}{|l|}{ Utilization of: } \\
\hline L-Rhamnose & + & + & + & - \\
\hline Raffinose & - & - & + & - \\
\hline D-Mannitol & - & + & + & + \\
\hline$i$-Inositol & + & + & + & - \\
\hline Sucrose & + & $\mathrm{D}$ & + & - \\
\hline Starch & + & + & - & + \\
\hline Nitrate reduction & + & - & + & + \\
\hline Growth at $45^{\circ} \mathrm{C}$ & + & + & - & - \\
\hline
\end{tabular}

* RF, Rectiflexibiles; SP, spirales. 


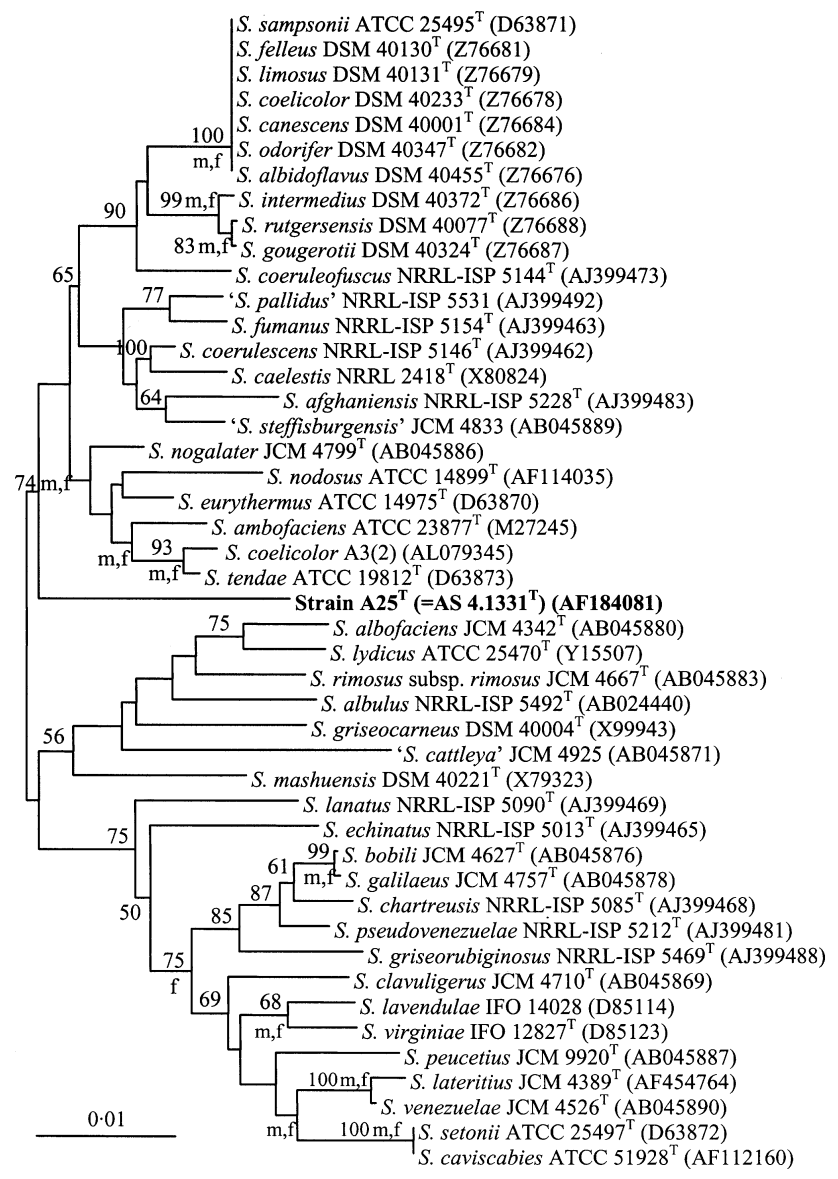

Fig. 2. Neighbour-joining tree based on nearly complete $16 \mathrm{~S}$ rDNA sequences of 45 streptomycetes. Branches labelled ' $f$ ' and ' $\mathrm{m}$ ' were also recovered when the Fitch-Margoliash and maximum-likelihood methods were used. Numbers at nodes indicate percentages of bootstrap support based on a neighbour-joining analysis of 1000 resampled datasets. Only values $>50 \%$ are given. Bar, 0.01 substitutions per nucleotide position.

taxon within the genus Streptomyces. Therefore, it is proposed that this organism be recognized as a novel species of the genus Streptomyces, Streptomyces scopiformis sp. nov.

\section{Description of Streptomyces scopiformis sp. nov.}

Streptomyces scopiformis (sco.pi.for'mis. L. fem. n. scopa a broom; L. fem. n. forma form; N.L. n. scopiformis in the form of a broom, referring to the structure of the spore chains).

Aerobic, mesophilic, Gram-positive. Substrate hyphae are extensively branching, septate and swollen. Rectiflexibles chains of roundish, spiny-surfaced spores $(0.7-0.8 \mu \mathrm{m})$ are arranged in fastigiate form. Spore mass is grey or blue-grey, the reverse is blue to greyblue. Diffusible pigment is not formed. Cell-wall type I, phospholipid type PII and menaquinone MK9 $\left(\mathrm{H}_{4,6}\right)$ are detected. The fatty acids are type II. Mycolic acids are not present. The $\mathrm{G}+\mathrm{C}$ content of the DNA is $71 \mathrm{~mol} \%$. Grows in presence of penicillin $\mathrm{G}$, biomycin, phenol and ethanol, at $20-45^{\circ} \mathrm{C}$ and at $\mathrm{pH} 5-10$ but not in the presence of bacteracin, lysozyme, sodium azide or methyl violet or at 10 or $50^{\circ} \mathrm{C}$ or at $\mathrm{pH} 4.0$ or 11.0. It utilizes L-arabinose, D-fructose, D-galactose, D-glucose, D-maltose, L-rhamnose, D-xylose, D-sucrose, dulcitol, meso-inositol, melibiose, trehalose, sodium acetate and sodium citrate as sole carbon sources but not D-mannitol, D-raffinose, adonitol, methyl $\alpha$-glucoside, $i$-erythritol or inulin. Tests for aesculin, starch, dextrin, elastin, nitrate reduction and gelatin are positive and tests for hippurate, cellulose and lipolysis are negative.

The type strain, $\mathrm{A} 25^{\mathrm{T}}$, has been deposited at the Chinese General Microbiological Collection Centre as strain AS $4.1331^{\mathrm{T}}\left(=\right.$ LMG $\left.20251^{\mathrm{T}}\right)$.

\section{ACKNOWLEDGEMENTS}

This study was performed within the framework of the Belgian-Chinese programme 'Identification and classification of actinomycetes, specifically bioactive Streptomyces strains isolated from Chinese soil', supported by MOST/ NSFC PR China and OSTC Belgium (BL/02/C10), and by the NSFC (grant no. 39970001). We also thank Dr D. E. Minnikin (Newcastle University) for the determination of fatty acid contents. The authors are also indebted to Professor R. M. Kroppenstedt (DSMZ) and Dr T. Kudo (JCM) for providing cultures.

\section{REFERENCES}

Al-Tai, A., Kim, B., Kim, S. B., Manfio, G. P. \& Goodfellow, M. (1999). Streptomyces malaysiensis sp. nov., a new streptomycete species with rugose, ornamented spores. Int J Syst Bacteriol 49, 1395-1402.

Anderson, A. S. \& Wellington, E. M. H. (2001). The taxonomy of Streptomyces and related genera. Int J Syst Evol Microbiol 51, 797-814. Chun, J. \& Goodfellow, M. (1995). A phylogenetic analysis of the genus Nocardia with $16 \mathrm{~S}$ rRNA gene sequences. Int J Syst Bacteriol 45, 240-245.

Collins, M. D. (1985). Isoprenoid quinone analysis in classification and identification. In Chemical Methods in Bacterial Systematics, pp. 267-287. Edited by M. Goodfellow \& D. E. Minnikin. London: Academic Press.

De Ley, J., Cattoir, H. \& Reynaerts, A. (1970). The quantitative measurement of DNA hybridization from renaturation rates. Eur $J$ Biochem 12, 133-142.

Embley, T. M. \& Stackebrandt, E. (1994). The molecular phylogeny and systematics of the actinomycetes. Annu Rev Microbiol 48, 257-289.

Felsenstein, J. (1981). Evolutionary trees from DNA sequences: a maximum likelihood approach. J Mol Evol 17, 368-376.

Felsenstein, J. (1993). PHYLIP (phylogeny inference package) version 3.5c. Department of Genetics, University of Washington, Seattle, USA. Fitch, W. M. \& Margoliash, E. (1967). Construction of phylogenetic trees: a method based on mutation distances as estimated from cytochrome $c$ sequences is of general applicability. Science 155, 279-284.

Hain, T., Ward-Rainey, N., Kroppenstedt, R. M., Stackebrandt, E. \& Rainey, F. A. (1997). Discrimination of Streptomyces albidoflavus strains based on the size and number of $16 \mathrm{~S}-23 \mathrm{~S}$ ribosomal DNA intergenic spacers. Int J Syst Bacteriol 47, 202-206.

Hasegawa, T., Takizawa, M. \& Tanida, S. (1983). A rapid analysis for chemical grouping of aerobic actinomycetes. J Gen Appl Microbiol 29, 319-322. 
Huß, V. A. R., Festl, H. \& Schleifer, K. H. (1983). Studies on the spectrophotometric determination of DNA hybridization from renaturation rates. Syst Appl Microbiol 4, 184-192.

Kämpfer, P., Kroppenstedt, R. M. \& Dott, W. (1991). A numerical classification of the genera Streptomyces and Streptoverticillium using miniaturized physiological tests. J Gen Microbiol 137, 1831-1891.

Kataoka, M., Ueda, K., Kudo, T., Seki, T. \& Yoshida, T. (1997). Application of the variable region in $16 \mathrm{~S}$ rDNA to create an index for rapid species identification in the genus Streptomyces. FEMS Microbiol Lett 151, 249-255.

Kawato, N. \& Shinobu, R. (1959). On Streptomyces herbaricolor sp. nov., supplement: a single technique for microscopical observation. Mem Osaka Univ Lib Arts Educ 8, 114-119.

Kim, D., Chun, J., Sahin, N., Hah, Y. C. \& Goodfellow, M. (1996). Analysis of thermophilic clades within the genus Streptomyces by $16 \mathrm{~S}$ ribosomal DNA sequence comparisons. Int $J$ Syst Bacteriol 46, 581-587.

Kim, S. B., Falconer, C., Williams, E. \& Goodfellow, M. (1998). Streptomyces thermocarboxydovorans sp. nov. and Streptomyces thermocarboxydus sp. nov., two moderately thermophilic carboxydotrophic species from soil. Int J Syst Bacteriol 48, 59-68.

Kimura, M. (1980). A simple method for estimating evolutionary rates of base substitutions through comparative studies of nucleotide sequences. $J$ Mol Evol 16, 111-120.

Kroppenstedt, R. M. (1985). Fatty acid and menaquinone analysis of actinomycetes and related organisms. In Chemical Methods in Bacterial Systematics, pp. 173-199. Edited by M. Goodfellow \& D. E. Minnikin. London: Academic Press.

Labeda, D. P. (1988). Kitasatosporia mediocidica sp. nov. Int J Syst Bacteriol 38, 287-290.

Lechevalier, M. P. \& Lechevalier, H. (1970). Chemical composition as a criterion in the classification of aerobic actinomycetes. Int $J$ Syst Bacteriol 20, 435-443.

Lechevalier, M. P., De Bièvre, C. \& Lechevalier, H. A. (1977). Chemotaxonomy of aerobic actinomycetes: phospholipid composition. Biochem Syst Ecol 5, 249-260.

Liu, Z. H. \& Zhang, Y. M. (1996). Streptomyces scopiformis sp. nov. Actinomycetes 7 (1), 23-27.

Lu, Z., Liu, Z., Wang, L., Zhang, Y., Qi, W. \& Goodfellow, M. (2001). Saccharopolyspora flava sp. nov. and Saccharopolyspora thermophila sp. nov., novel actinomycetes from soil. Int J Syst Evol Microbiol 51, 319-325.
Maidak, B. L., Olsen, G. J., Larsen, N., Overbeek, R., McCaughey, M. J. \& Woese, C. R. (1997). The RDP (Ribosomal Database Project). Nucleic Acids Res 25, 109-111.

Marmur, J. \& Doty, P. (1962). Determination of base composition of deoxyribonucleic acid from its denaturation temperature. $\mathrm{J} \mathrm{Mol} \mathrm{Biol} \mathrm{5,}$ 109-118.

Minnikin, D. E., Hutchinson, I. G., Caldicott, A. B. \& Goodfellow, M. (1980). Thin-layer chromatography of methanolysates of mycolic acid containing bacteria. J Chromatogr 188, 221-233.

Saitou, N. \& Nei, M. (1987). The neighbor-joining method: a new method for reconstructing phylogenetic trees. Mol Biol Evol 4, 406-425.

Thompson, J. D., Gibson, T. J., Plewniak, F., Jeanmougin, F. \& Higgins, D. G. (1997). The CLUSTAL_X windows interface: flexible strategies for multiple sequence alignment aided by quality analysis tools. Nucleic Acids Res 25, 4876-4882.

Waksman, S. A. \& Henrici, A. T. (1943). The nomenclature and classification of the actinomycetes. $J$ Bacteriol 46, 337-341.

Warwick, S., Bowen, T., McVeigh, H. \& Embley, T. M. (1994). A phylogenetic analysis of the family Pseudonocardiaceae and the genera Actinokineospora and Saccharothrix with 16S rRNA sequences and a proposal to combine the genera Amycolata and Pseudonocardia in an emended genus Pseudonocardia. Int J Syst Bacteriol 44, 293-299.

Williams, S. T., Goodfellow, M., Alderson, G., Wellington, E. M. H., Sneath, P. H. A. \& Sackin, M. J. (1983). Numerical classification of Streptomyces and related genera. J Gen Microbiol 129, 1743-1813.

Williams, S. T., Goodfellow, M. \& Alderson, G. (1989). Genus Streptomyces Waksman and Henrici 1943, 339 ${ }^{\mathrm{AL}}$. In Bergey's Manual of Systematic Bacteriology, vol. 4, pp. 2452-2492. Edited by S. T. Williams, M. E. Sharpe \& J. G. Holt. Baltimore: Williams \& Wilkins.

Yassin, A. F., Galinski, E. A., Wohlfarth, A., Jahnke, K.-D., Schaal, K. P. \& Trüper, H. G. (1993). A new actinomycete species, Nocardiopsis lucentensis sp. nov. Int J Syst Bacteriol 43, 266-271.

Yassin, A. F., Rainey, F. A., Burghardt, J., Gierth, D., Ungerechts, J., Lux, I., Seifert, P., Bal, C. \& Schaal, K. P. (1997). Description of Nocardiopsis synnemataformans sp. nov., elevation of Nocardiopsis alba subsp. prasina to Nocardiopsis prasina comb. nov., and designation of Nocardiopsis antarctica and Nocardiopsis alborubida as later subjective synonyms of Nocardiopsis dassonvillei. Int J Syst Bacteriol 47, 983-988. Zhou, Z.-H., Liu, Z.-H., Qian, Y.-D., Kim, S. B. \& Goodfellow, M. (1998). Saccharopolyspora spinosporotrichia sp. nov., a novel actinomycete from soil. Int J Syst Bacteriol 48, 53-58. 